\title{
SLOVENSKO PODEŽELJE NA PREIZKUŠNJI - kdo bo nadomestil kmetijstvo?
}

\author{
Marjan Ravbar \\ Geografski inštitut Antona Melika ZRC SAZU, Trg francoske revolucije 7, Ljubljana \\ e-mail: marjan.ravbar@zrc-sazu.si
}

Pregledni znanstveni članek

COBISS 1.02

\section{Izvleček}

Prispevek pojasnjuje vlogo podeželja v sodobnih družbenih procesih s poudarkom in na pomenu prepletanj med mesti in podeželjem. Poudarek je na pregledu sodobnih teženj v razvoju naselij in rabe površja. Z njimi opozarjamo na procese, ki potekajo v nasprotju $\mathrm{Z}$ želenimi cilji. S simuliranjem razvojnih posledic v več tipičnih območij z različnimi razvojnimi možnostmi se opirajoč na spontane procese opredeljujemo do zaraščanja kmetijskih zemljišč in preobrazbe kmetijskih zemljišč v stavbna zemljišča. V zaključku s pomočjo simulacijskega modela podajamo možne usmeritve za nadaljnji gospodarski razvoj na podeželju.

Ključne besede: podeželje, tipologija naselij, kmetijska usmerjenost, razvoj podeželja, regionalna politika.

\section{PUTTING SLOVENE COUNTRYSIDE TO THE TEST - who will replace agriculture?}

\begin{abstract}
The paper explains the role of countryside in modern social processes and the importance of its intertwining with cities. We emphasize the overview of modern trends in settlement development and land use and point out the processes that do not correspond with planned goals. Through simulating developmental consequences in several typical areas of different developmental possibilities and by referring to spontaneous processes, we are discussing the overgrowth of agricultural land and its transformation into built up space. At the end we offer a possible direction for future countryside development with the help of a simulation model.
\end{abstract}

Key words: countryside, typology of settlements, agricultural orientation, countryside development, regional policy. 


\section{UVOD}

Dolgoletna spremljanja preobrazbe slovenskega podeželja so pokazala, da sta se postopno oblikovali dve območji s povsem specifičnimi razvojnimi problemi (gl. npr. Klemenčič, 1991 in 2005). Na eni strani razlikujemo urbanizirana ravninska območja, čigar teritorij se na obrobju območij gospodarske in populacijske koncentracije postopno širi proti odročnejšim območjem. Na drugi strani pa se spreminjajo tudi »tradicionalna« podeželska območja. Ta diferenciacija je bila spontana, pa najsi gre za depopulacijo perifernih in hribovitih vasi ter zaselkov ali pa za stihijsko koncentracijo prebivalstva v obmestnih naseljih, ki jo spremlja razpršena stanovanjska gradnja individualnih stanovanjskih hiš, pogojena $\mathrm{z}$ liberalnim nakupom zemljišč in premalo selektivno urbanistično politiko. Prvo se dogaja v obsegu ugodne dostopnosti do delovnih mest, drugo pa v odročnih, prometno slabše dostopnih hribovitih in kraških območjih. V zaledju zgostitvenih območij imajo podeželska območja vsestransko ugoden gospodarski razvoj in relativno napredno tržno usmerjeno kmetijstvo.

Intenzivna preobrazba podeželja, ki ji sledimo že desetletja, poteka dlje časa. V drugi polovici preteklega stoletja je bila v prvi vrsti odsev družbenih procesov, ki so jo označevali deagrarizacija, industrializacija, urbanizacija, itd. Ob prelomu v 21. stoletje pa so to postfordizem, konkurenčnost (tekmovalnost) in prehod v informacijsko družbo, skratka vseobsežna modernizacija družbe. Vse to povzroča spremembe v vlogi in funkciji podeželskih območij. Kmetijstvo na slovenskem podeželju že nekaj časa nima več odločujoče vloge v gospodarskem razvoju. Podeželje in njegov razvoj sta bolj in bolj odvisna od urbanega središča in zaposlitvenih možnosti izven kmetijstva. Spremembe v gospodarski zgradbi podeželja so še posledica delovanja številnih, kompleksnih in nasprotujočih si silnic (npr. intenzifikacija in diverzifikacija na eni ter pomanjkanja inovativnosti in razvojnih spodbud, itd. na drugi strani) ter so z geografskega vidika regionalno in lokalno zelo raznoliki. Preobrazbo pospešujejo relativno cenene možnosti za raznolike graditeljske aktivnosti, ki so pogosto v veliki meri odsev nezdravih razmer na trgu nepremičnin, npr. pri zemljiški politiki (zemljiško-posestne razmere, nizka zemljiška renta, ...) in s tem povzročajo dodatne pritiske na pretežno kmetijske površine. Pogosto pa so tudi odziv na problematično načrtovanje razvojnih zamisli in presoj. Pri tem velja še opozoriti, da so planerska izhodišča običajno kompromis med strokovnimi pogledi ter objektivnimi ali subjektivnimi preferencami političnega ravnanja za doseganje družbene sprejemljivosti.

Pričujoči prispevek temelji na doslej opravljenih avtorjevih raziskavah proučevanja prepletanj med mesti in podeželjem ter empiričnih izkušnjah o pomenu podeželja pri usmerjanju regionalnega razvoja v sodobnih družbenih procesih. Poudarek je na pregledu sodobnih teženj v razvoju naselij, povezanih s spremembami v rabi površja. S kritičnim razmišljanjem želimo opozoriti predvsem na težnje, ki potekajo v nasprotju z želenimi cilji usmerjanja razvoja podeželja. Izhajajoč iz gornjih predpostavk želimo opozoriti na naslednja razvojna vprašanja:

- Ali se bo nadaljeval proces zaraščanja kmetijskih zemljišč in kako se (bo) spreminja(la) kulturna pokrajina?

- Ali je pričakovati pospešitev procesa koncentracije kmetijske posesti in pridelovalnih zemljičč? 
- Kakšen bo gospodarski razvoj na podeželju? Kako daleč od mestnih središč lahko še pričakujemo stabilen razvoj?

- Ali se bo nadaljeval proces preobrazbe kmetijskih zemljišč v stavbna zemljišča in kakšen bo gospodarsko - geografski naselbinski razvoj na podeželju?

$\mathrm{S}$ simuliranjem razvojnih posledic $\mathrm{v}$ več tipičnih območij $\mathrm{z}$ različnimi razvojnimi možnostmi, se opirajoč na spontane procese, ki kot posledica nekoordiniranih politik že potekajo v pokrajini, tako opredeljujemo do zaraščanja kmetijskih zemljišč v gozdna, kot tudi do preobrazbe kmetijskih zemljišč v stavbna. V zaključku pa s pomočjo simulacijskega modela podajamo možne usmeritve za nadaljnji gospodarski razvoj na podeželju.

\section{KAJ JE PODEŽELJE?}

Po Geografskem terminološkem slovarju (2005) »... podeželje predstavlja kultivirano pokrajino kjer je v pokrajinskem videzu in rabi prostora opazna prevlada najpomembnejših dejavnosti kmetijstva in gozdarstva. V njem živi nadpovprečen delež kmečkega prebivalstva, ki je bolj preprosto socialno razčlenjeno. Poleg tega je v njem še tradicionalna in poudarjena prilagojenost položaja naselij in oblik hiš naravnim razmeram...« (str. 286). Tudi statistično razvrščanje podeželskih naselij je prilagojeno gornji definiciji in temelji na demografskih, gospodarskih in morfoloških kazalnikih razmejevanja naselij med mestnimi in ostalimi območji. Upoštevajoč gornje kriterije, obsega podeželje $96 \%$ slovenskega teritorija na katerem prebiva dobra polovica prebivalstva (Ravbar, 1997). Glede pojmovanja podeželja je v prostorskem in razvojnem planiranju še več nejasnosti, kjer je najpogosteje odsotna jasna razmejitev. Tako so v novejših razvojnih programih in prostorskih strategijah pogosto uporabljeni pojmi »podeželje« in »podeželska območja«, katerih predstavitve pa ne temelje na enotnih kriterijih; to povzroča nemalo zmede.

Proučevanje in opredeljevanje podeželja je plod dolgoletnega zanimanja predvsem geografov. Na postopno zabrisano in težko razpoznavno preobrazbo podeželja so iz različnih zornih kotov opozarjali zlasti Klemenčič (npr: 1953, 1960 in 1991), Kokole (1969 in 1988), Vrišer (1964 in 1974), Sedlar (1974), Gosar in Mihevc (1977 in 1982), Kovačič s sodelavci (2000), Barbič (2005) in tudi drugi. Skupni imenovalec naštetih študij, ki so nastajale v različnih časovnih obdobjih in na podlagi medsebojno težko primerljivih metodologij, je v različnih členitvah in opozarjanju na ključne probleme, kar ni nič narobe - še več - razkriva nam vso razvejanost in kompleksnost razsežnosti proučevanj podeželja. Opravljene raziskave so s tem tudi tradicionalno oznako podeželja kot življenjskega območja za pretežno podeželsko prebivalstvo - kot značilne prispodobe za slovensko nacionalno identiteto - že pred desetletji postavile pod vprašaj.

Tudi v obsežni tuji literaturi so pojmovne opredelitve za npr.: »ländlicher Raum«, »éspace rural«, »région rurales« ali »campagne« neenotne. So pa v OECD (2002) v zadnjih letih razvili kompleksna izhodišča za členitev podeželja. Navezujejo se na dejstvo, da v sodobnosti mesto in podeželje več ne tekmujeta, ampak se medsebojno funkcijsko dopolnjujeta. Še vedno pa med njima ostaja poglavitna razlika, ki je posledica: (a) različne gostote poseljenosti, (b) 
razlik v socialno ekonomski strukturi z vidika zaposlovanja in števila delovnih mest, (c) visoki stopnji funkcijske odvisnosti podeželja od mest in končno, (d) velikih razlik na področju infrastrukturne opremljenosti ter v stopnji specializacije (zlasti) služnostnih dejavnosti.

Navkljub (sicer raznorodnim) definicijam podeželskih območij, kot komplementarnem območju nasproti mestom, sta prebivalstveni in ekonomski razvoj $\mathrm{v}$ njih soodvisna. Razseljevanje prebivalstva in enakomernejša razporeditev delovnih mest - ki naraščata predvsem $\mathrm{v}$ urbaniziranih obmestjih - sta posledica tehnoloških sprememb, preobrazbe gospodarskih in družbenih struktur, ki tudi Slovenijo vodijo v obdobje "urbanega razvoja brez demografske rasti”. Le-tega v grobem označujeta prostorska širitev mestnih vplivov v obmestja in notranja preobrazba celotne mestne pokrajine. Povezan je s spreminjanjem dohodkovno ekstenzivnejših rab prostora $\mathrm{v}$ intenzivnejše. $Z$ razpršenim naselbinskim razvojem $\mathrm{v}$ zadnjih desetletjih postajajo razlike med mesti in podeželjem vedno težje razpoznavne. Tudi socialno geografske predstave o pojmu podeželja še vedno niso enoznačne. Tako se npr. prebivalci, ki žive v relativno gosto poseljenih obmestjih izven mest običajno še vedno prištevajo med »podeželane « kljub temu, da ima njihovo življenjsko okolje in način življenja malo skupnega $\mathrm{s}$ tradicionalnim pojmovanjem podeželja.

Ne glede na pomembna skupna obeležja pa je podeželje vedno bolj heterogeno, posebej v izkoriščanju naravnih pogojev in razvojnih potencialov ter možnostih njihove izrabe na področju demografskih in gospodarskih struktur kot tudi $\mathrm{v}$ funkcionalnih povezavah $\mathrm{z}$ mestnimi središči kot razvojnimi generatorji. Prav zato obsežna (praviloma odročnejša, hribovita, kraška) območja še vedno zapadajo v letargijo (Ravbar, 2004).

\section{PREPLETANJA MEST IN PODEŽELJA: TIPIZACIJA NASELIJ}

V sodobnosti je prepletenost urbanih in podeželskih elementov pomembna sestavina naselbinskega razvoja. Podeželje je danes $\mathrm{v}$ mnogoterih pogledih povezano $\mathrm{z}$ mesti in izpopolnjuje številne pomembne funkcije za celotno pokrajino. $V$ prvi vrsti se spreminja $v$ življenjski in gospodarski prostor za bivanje in delo. Tu ob porastu stanovanjskih površin ne srečujemo več samo kmetijskih obratov oz. klasičnih podeželskih struktur (kjer tudi proizvodnja hrane ni zanemarljiva), ampak $v$ vse večjem obsegu tudi drobna in srednje velika industrijska podjetja (podobno kot $\mathrm{v}$ fazi razpršene industrializacije) ter široko ponudbo trgovskih in drugih dejavnosti.

Če pogledamo kot celoto, je podeželje sicer samobitno, istočasno pa ga je nasproti urbaniziranim območjem razumeti kot komplementarno območje. Najprej gre za součinkovanje, ki ga skozi partnerski odnos med mesti in podeželjem na specifičen način izkorišča - izrablja - tako mestno kot podeželsko prebivalstvo. Za bližnji, »vmesni« prostor med mesti in podeželjem se je uveljavil pojem »obmestje«. Zanj velja, da gre v prvi vrsti za razširitev in prilagajanje različnih neagrarnih človekovih dejavnosti iz mest proti podeželju. Obmestja tako predstavljajo najvitalnejše življenjsko in hkrati gospodarsko območje za bivanje in delo. Prav zato jih spremljajo intenzivni in preobražajoči se procesi v demogeografski, zaposlitveni in socialni sestavi prebivalstva, s čimer se spreminja ekonomska, funkcijska in fiziognomska struktura široke (ob)mestne pokrajine. 
Novejše analize naselbinskega sistema (Ravbar, 1997 in 2004) so pokazale visoko stopnjo medsebojne socialne in ekonomske prepletenosti mest s podeželjem pri vseh večjih slovenskih mestih (z nad 20000 prebivalci). Ta mesta (nacionalnega pomena) običajno obkrožajo venci nekdanjih podeželskih vasi v najožji suburbanizirani okolici in nato še nekoliko dlje - 10 do $15 \mathrm{~km}$, ali do okoli 30' časovne izohrone (v primeru Ljubljane ja ta pas bistveno obsežnejši) - sledi širši pas prav tako močno urbaniziranih obmestnih naselij s prepletanjem agrarnih in neagrarnih dejavnosti. Šele zatem sledi postopen prehod v podeželsko pokrajino. Obe raziskavi sta pokazali, da ob prelomu stoletja v najbližjih suburbaniziranih obmestjih prebiva skupaj skoraj desetina prebivalstva (9\%) in nato še osmina $(12 \%)$ v močno urbaniziranih obmestnih naseljih. Izrazito urbanizirana, urbanizirana podeželska in pol urbanizirana prehodna območja naselij pa so štela še nadaljnjih $13 \%$ prebivalstva. Tako v tretjini (1903) močno urbaniziranih (po fiziognomskem videzu sicer podeželskih) naseljih prebiva dobra tretjina (34\%) prebivalstva, kjer delež kmečkega prebivalstva v povprečju dosega komaj odstotek ali dva od skupnega števila prebivalcev. Zanj so značilni nagli preobražajoči se procesi, katerim ob prostorski rasti naselij daje odločujoč pečat še visoka stopnja mobilnosti prebivalstva, naraščanje števila delovnih mest in visoka stopnja dnevne delovne migracije.

$\mathrm{Na}$ drugi strani pa lahko obsežne dele Slovenije še vedno označujemo kot »klasična« podeželska območja. Le-ta $\mathrm{z}$ gospodarskega in populacijskega vidika zaostajajo v razvoju. Tako definirano podeželje (več o tem v: Ravbar, 1997) predstavlja dve tretjini ozemlja države. Na njem v 3.942 naseljih prebiva dobrih štiristo tisoč prebivalcev. Ločujemo tri skupine naselij podeželskih območij. Manj obsežna so tista s stabilnim demografskim razvojem, uravnoteženo selitveno bilanco in še zadovoljivo socialno in ekonomsko geografsko strukturo kjer je šestina kmečkega prebivalstva. Štejejo četrtino naselij in prav toliko površja ter skupaj skoraj dvesto tisoč prebivalcev. Gostota poseljenosti dosega polovico državnega povprečja. Sestavljajo jih majhna naselja, katere povprečna velikost je komaj okoli 130 prebivalcev. Najštevilčnejšo skupino sestavlja 1.764 pretežno ogroženih naselij, ki skupaj štejejo 177 tisoč prebivalcev in so v zadnjih treh desetletjih izgubila četrtino prebivalstva (povprečna letna stopnja je - 0,92). Celotno območje pretežno ogroženih naselij predstavlja tretjino območja države. Še posebej zaskrbljujoče razmere so v 729 naseljih (12 \% vseh naselij), ki so v zadnjih treh desetletjih izgubila več kot tretjino prebivalstva, v zadnjem desetletju pa sedmino. To so danes majhna naselja, katerih povprečna velikost ne presega 70 prebivalcev. $V$ teh pretežno odmirajočih naseljih, z ostarelim prebivalstvom, je zaradi pomanjkanja števila delovnih mest izrazita in močno nadpovprečna dnevna migracija. Gostota poseljenosti je le 17 prebivalcev $/ \mathrm{km}^{2}$, oz. šestina državnega povprečja.

\section{SPREMEMBE V RABI POVRŠJA KOT EKONOMSKI PODLAGI ZA RAZVOJ PODEŽELJA: NARAŠČANJE NEENAKOSTI?}

Spremljanje stanja temeljnih zemljiških kategorij, ki ga s pomočjo statističnih podatkovnih baz na podlagi tekočega zaznavanja spremlja Statistični urad RS, se je v zadnjem desetletju bistveno izboljšalo. Na podlagi sodobnih podatkov statističnega informacijskega sistema 
(StatGIS) o »Pokrovnosti tal Slovenije« (SURS, 2005) je od leta 1993 do 2001 omogočeno podrobnejše spremljanje preobrazbe nekaterih temeljnih zemljǐ̌kih kategorij kot so kmetijske, gozdne in pozidane (poseljene) površine.

Primerjava podatkov v opazovanem obdobju nas opozarja, da so največje spremembe povezane s povečanjem gozdnih in zmanjšanjem kmetijskih površin. Kmetijske površine so se zmanjšale za 150.945 ha ali za petino. Po drugi strani pa so se gozdne površine razširile za 138.409 ha ali za osmino (gl. preglednico št. 1 ter grafikona št. 1 in 2). Gozdne površine so se najbolj povečale na območju obalno-kraške (za 33 \%) in goriške statistične regije ter najmanj na Koroškem (za 3 \%). Kmetijske površine pa so se zopet najbolj zmanjšale na obalno-kraškem, goriškem in gorenjskem območju (med 39 in 35 \%), najmanj pa v Pomurju (za 5 \%).

Preglednica 1: Spremembe v rabi površin pri izbranih kategorijah zemljišč v Sloveniji v obdobju 1993 - 2001 (v ha).

Table 1: The changes in land use in selected categories in Slovenia during the period 1993-2001 (ha).

\begin{tabular}{|c|r|r|r|r|r|r|}
\hline leto & $\begin{array}{r}\text { gozdne } \\
\text { površine }\end{array}$ & indeks & $\begin{array}{r}\text { kmetijske } \\
\text { površine }\end{array}$ & indeks & $\begin{array}{r}\text { pozidane } \\
\text { površine }\end{array}$ & indeks \\
\hline 1993 & 1145031 & 1.00 & 770126 & 1.00 & 60357 & 1.00 \\
\hline 2001 & 1283440 & 1.12 & 619181 & 0.80 & 78788 & 1,31 \\
\hline
\end{tabular}

Vir / Source: SURS, 2005

Pričujoči podatki opozarjajo tudi na pomembne spremembe v pozidanih površinah in temelje na podatkih centroidov EHIŠ hiš kar pomeni, da podatki omogočajo spremljanje sprememb površin pod stavbami. Tako je bilo npr. v obdobju zadnje dekade na prelomu stoletja ob stagnaciji števila prebivalstva zgrajenih 90.852 stanovanj, od tega po ocenah okoli $4 / 5$ v enodružinskih prosto stoječih hišah na privatnih zemljiščih. Stanovanjska rast se povečuje pretežno na račun zmanjševanja povprečnega števila članov na gospodinjstvo (obenem narašča število samskih gospodinjstev). Uradni statistični podatki kažejo, da se je obseg pozidanih površin med 1993 in 2001 povečal za 18.431 ha. Povprečni indeks sprememb v osemletnem obdobju je $131 \%$, ali v 2.304 ha letno, oz. 6,3 ha/dan (!). Med statističnimi regijami so se nova stavbna zemljišča v opazovanem obdobju povečala za več kot 2000 ha v Osrednji Sloveniji, Podravju in Savinjskem. Nadpovprečno relativno stopnjo sprememb pa beležimo na Goriškem, Koroškem, Posavju, Zasavju, Dolenjskem in obalno-kraškem območju. Porast poselitvenih površin ima nazorno odslikavo v zmanjšanju kmetijskih površin. Nadpovprečne spremembe opazujemo zlasti na obrobjih mest, ne glede na njihovo velikost in položaj v hierarhični zasnovi urbanega omrežja in prav tako na podeželju. Tu so se zazidane površine povečale za 16.367 ha kar je 87 \% od vseh na novo pozidanih površin. Z obstoječimi podatkovnimi bazami je moč analizirati tudi razmerja med različnimi podskupinami pozidanih zemljišč. Tako npr. površine naselij predstavljajo 71 \% medtem, ko je preostalih 29 \% površin zasedajo različni infrastrukturni objekti in naprave med katerimi prevladuje cestno omrežje (gradnja avtocestnega prometnega križa). 
Graf 1: Spremembe v rabi površin pri izbranih kategorijah zemljišč v Sloveniji v obdobju 1993 -2001 (v ha).

Figure 1: The changes in land use in selected categories in Slovenia during the period 1993-2001 (in ha).

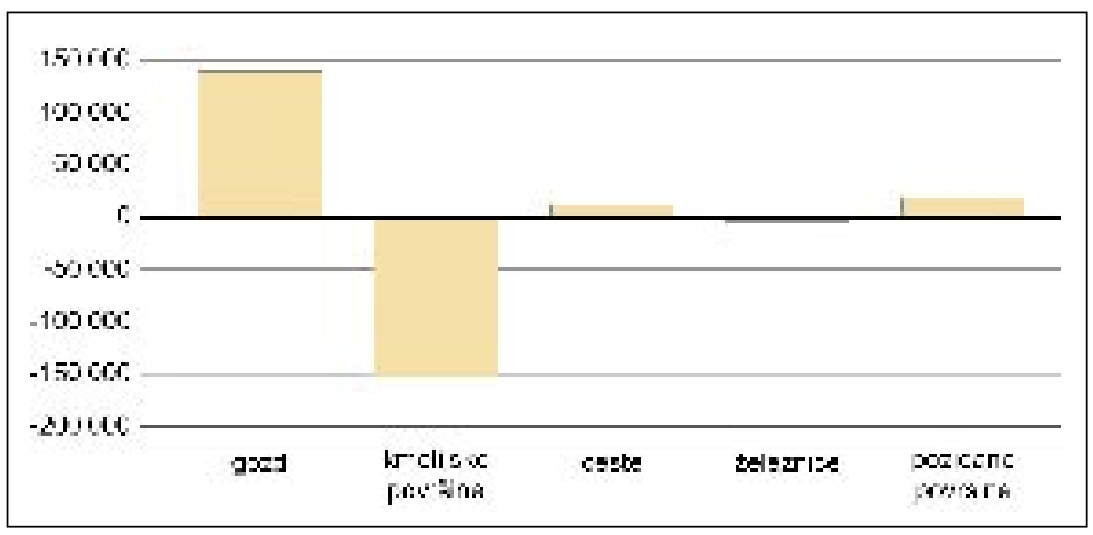

Graf 2: Spremembe v rabi površin pri izbranih kategorijah zemljišč po statističnih regijah v obdobju 1993 - 2001 ( $v \%)$.

Figure 2: The changes in land use in selected categories in Slovenia during the period 1993-2001 (in \%).

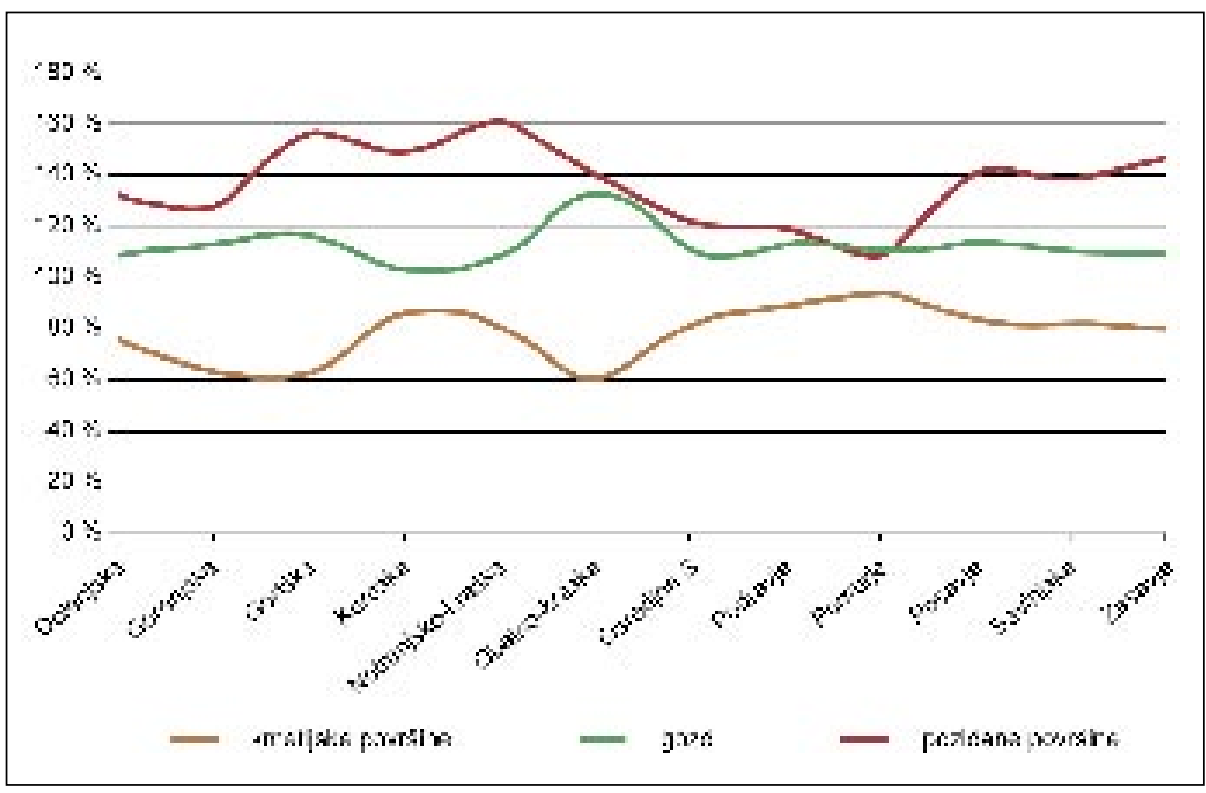


Kljub temu, da gre za uradne statistične podatke in relativno kratko časovno obdobje spremljanja, zgoraj opisane spremembe vseeno vzbujajo določene dvome o verodostojnosti zajetih podatkov. Toda $\mathrm{v}$ pričujočem prispevku ni naš namen, da vrednotimo primernost uporabljenih metod pri določanju namenske rabe površin. Pač pa želimo (tudi z nekritičnim) povzemanjem podatkov opozoriti zgolj na težnje in strukturne spremembe, ki se v zadnjem obdobju odvijajo v posameznih tipih slovenskega naselbinskega sistema.

Dostopne podatkovne baze o aktualnih spremembah $\mathrm{v}$ rabi površin nam potemtakem služijo zgolj kot vodilo za oblikovanje kritičnih premis, kijih sprožajo gospodarska ali družbeno politična ozadja z odsevnostjo v ekonomskih aktivnostih, ki sprožajo neenakosti na podeželju. Vedno razločneje se namreč ustvarja vtis, da je ta preobrazba odsev strukturnih sprememb, povezanih s socialno-demografskim, ekonomskim in zaposlitvenim razvojem v nekmetijskih dejavnostih. S tem so povezana vrednotenja in vzročna povezanost med razvitostjo podeželja, stopnjo urbaniziranosti in spremembami v rabi površja (več o tem v: Ravbar, Kladnik, 2003). Primerjava je pokazala, da obstajajo pomembne razlike med obmestnimi območji v gravitacijskem zaledju mest in urbaniziranih naselij ter odročnejšimi podeželskimi-praviloma hribovitimi/gorskimi in/ali kraškimi območji. Na območjih z najvišjo stopnjo razvitosti podeželja so tudi vse (naj)večje mestne aglomeracije, kar predstavlja pomembne izzive tudi za prihodnost našega kmetijstva. $V$ teh območjih je zmanjševanje kmetijskih površin zaradi opuščanja kmetovanja, izračunano s pomočjo količnika med spremembami v kmetijski rabi in naraščanjem pozidanih površin, petkrat manjše kot $\mathrm{v}$ ostalih podeželskih območjih. To zlasti velja za Ljubljansko kotlino, Dravsko-ptujsko polje, Spodnjo Vipavsko, Srednjo Savinjsko ter Krško-brežiško dolino.

Na območjih z (naj)manj ugodnimi razvojnimi potezami prevladujejo podeželska vaška naselja, ki po svojih demografskih značilnostih sodijo v skupino razvojno ogroženih ali celo odmirajočih naselij. Toda tu so spremembe v rabi vseh treh zemljiških kategorij najbolj intenzivne: kmetijske površine so se zmanjšale za 124.242 ha kar je $82 \%$ od celokupnega zmanjšanja kmetijskih površin v Sloveniji. Toda ob tem so se gozdne površine povečale za 118.182 kar spet pomeni $85 \%$ od celokupnega povečanja gozda. Na podeželju pa so se kljub upadanju prebivalstva povečala stavbna zemljišča za 11.328 ha kar predstavlja $60 \%$ vseh sprememb med pozidanimi območji.

Strukturna, naselbinska in socialno geografska preobrazba na prelomu stoletja, ima tudi daljnosežne posledice $v$ hitrem spreminjanju namenske rabe površja razumljene nemalokrat tudi kot razvrednotenje pokrajinske podobe ali tudi kot izgubo podeželskega »imidža« (Bryant, 1997). Izbor poglavitnih razlik na taksativni ravni prikazuje spodnja preglednica.

Pri presoji o možnostih razvoja kmetijstva na podeželju je neogibno oblikovanje členitve v več tipičnih območij z različnimi razvojnimi možnostmi in scenariji. Členitev, ki se v Sloveniji že nakazuje - morda sicer ne tako izrazito kot v razvitejših evropskih deželah - je naslednja:

Območja konkurenčnega tržnega kmetijstva: Ta se bodo še nadalje intenzivirala. Sledila bodo nakazanim razvojnim smerem, kot so koncentracija posesti in zemljišč, povečan zakup zemljišč, povečanje naložb v tehnološke izboljšave in na ta način povečevanje produktivnosti, intenziviranje in specializacija proizvodnje, naraščanje števila »varnih« kmetijskih obratov, 
Preglednica 2: Razlike v razvitosti podeželja in spreminjanje nekaterih funkcij regionalnogeografskih dejavnikov v pokrajini.

Tabel 2: The diferences in developmental stage of rural areas and changes of some functions of regional-geographical factors in the landscape.

\begin{tabular}{|c|c|c|}
\hline & nizka stopnja razvitosti podeželja & $\begin{array}{c}\text { visoka stopnja razvitosti } \\
\text { podeželja }\end{array}$ \\
\hline pokrajinski videz & $\begin{aligned} \text { - tradicionalna podeželska pokrajina } \\
\text { z znaki propadanja, } \\
\text { - razprostranjenost obdelovalnih } \\
\text { površin ob vaških naseljih, }\end{aligned}$ & $\begin{array}{l}\text { - „dvosmeren « proces } \\
\quad \text { drobljenja in koncentracije } \\
\quad \text { posesti hkrati, } \\
\text { - "vrtičkarska" raba površin v } \\
\text { obmestjih, } \\
\text { - posebne (tržno zanimive) } \\
\quad \text { kulture,... }\end{array}$ \\
\hline raba površja & $\begin{array}{l}\text { - prevlada obdelovalnih površin, } \\
\text { - odgovoren odnos do pokrajinske } \\
\text { slike, } \\
\text { - prehranski obrati, sadovnjaki, } \\
\text { pašniki... } \\
\text { - ekstenzifikacija obdelovalnih } \\
\text { površin, } \\
\text { - mehanizacija proizvodnje, ... }\end{array}$ & $\begin{aligned} \text { - krčenje kmetijskih površin, } \\
\text { - zatravljanje površin, } \\
\text { - nenačrtno ogozdovanje } \\
\text { - neodgovoren odnos do } \\
\text { pokrajinske slike podeželja in } \\
\text { kmetijskih površin, } \\
\text { - „ekologizacija« kmetijstva s } \\
\text { pomočjo finančnih spodbud, } \\
\text { - } \text { modernizacija kmetijske } \\
\text { proizvodnje, }\end{aligned}$ \\
\hline $\begin{array}{l}\text { položaj kmetijskih } \\
\text { površin }\end{array}$ & $\begin{array}{l}\text { - izraba vseh možnih površin, tudi } \\
\text { v neugodnih legah (ozke doline, } \\
\text { kraške vrtač, } \\
\text { - ogrožen, vendar prilagodljiv, }\end{array}$ & $\begin{array}{l}\text { - izraba v ravninskih območjih, } \\
\text { prodnih ravnicah in v bližini } \\
\text { naselbinskih območij, } \\
\text { - inovativni obrati, }\end{array}$ \\
\hline zakup - najem zemljišč & - neznaten & - visok \\
\hline gostota delovnih mest & - neznatna & - naraščajoča, visoka \\
\hline rodovitnost-donosnost & - neznatna, srednja & - visoka \\
\hline $\begin{array}{l}\text { posestna struktura - } \\
\text { parcelizacija }\end{array}$ & - mešana & - drobna \\
\hline $\begin{array}{l}\text { razvojna dinamika } \\
\text { podeželja }\end{array}$ & - tradicionalna, zastarela, & - težnje zaokroževanja posesti, \\
\hline $\begin{array}{l}\text { usmerjanje podeželja } \\
\text { in planski instrumenti } \\
\text { (cilji, strategije...) }\end{array}$ & $\begin{array}{l}\text { - varovanje prednostnih območij za } \\
\text { kmetijstvo (kvantitatino), } \\
\text { - nezaupanje do tržnih mehanizmov, } \\
\text { - direktno trženje kot znamenje za } \\
\text { prilagajanje tržnim razmeram in } \\
\text { sanacijo stanja. }\end{array}$ & $\begin{array}{l}\text { - kvalitativno varovanje } \\
\text { prednostnih območij za } \\
\text { kmetovanje, } \\
\text { - poudarek na informacijah, } \\
\text { motiviranosti in koordinaciji, } \\
\text { - direktno trženje kot znamenje } \\
\text { za prilagoditev, } \\
\text { - skeptičen odnos do tržne } \\
\text { liberalizacije in reguliranja na } \\
\text { ravni EZ. }\end{array}$ \\
\hline
\end{tabular}


zmanjševanje živalske proizvodnje (meso in mleko), ipd. V Sloveniji je (bil) ta proces doslej dokaj počasen. Odvisen pa je vendarle od kmetijske politike, ki bo morala intenzivneje usmerjati ta proces. Liberalizacija cen, ki naj bi pomenila prvi steber reforme kmetijske politike, bo proces pospeševala. Intenzifikacija naj bi (pogojno) dosegala ravni produktivnosti, ki bi lahko bile konkurenčne (tudi) neagrarnim dejavnostim. Nekatere kmetijske panoge se opazno razvijajo v to smer, npr. vrtnarstvo, vinogradništvo, sadjarstvo (v določenih okoljih) ipd. vendar je takih območij v Sloveniji malo. Že omenjena liberalizacija cen nakazuje razvoj v tej smeri, čeprav se bo to v Sloveniji dogajala na sorazmerno omejenem prostoru, predvsem zaradi (neugodnih) naravnih razmer. Zato je pričakovati še nadaljevanje strukturne diferenciacije med podeželskimi območji. Posamezni empirični primeri nakazujejo razvojno smer (npr. Goriška Brda).

Območja diverzifikacije dejavnosti na podeželju: To naj bi bila tista vmesna območja, kjer kmetijstvo potrebuje podporo od drugih gospodarskih dejavnosti predvsem zaradi ohranjanja poselitve, premagovanja prenaglih socialnih sprememb - socialnih stresov, varstva naravne in kulturne pokrajine in podpore drugim gospodarskim dejavnostim, npr. turizmu. Hkrati so to lahko tudi območja, kjer je mogoče uveljaviti tudi gospodarsko donosne oblike kmetijske pridelave, npr. lokalno značilne proizvode, posebne pridelke, ki zaradi svoje posebnosti, npr. zdravstvene neoporečnosti, posebnih organoleptičnih lastnosti ipd. dosegajo višje cene na trgu. $V$ resnici se bodo ta območja v največji meri ohranjala $z$ drugim stebrom reforme kmetijske politike, to je z neposrednimi plačili/ha. Obseg teh plačil bo nedvomno usmerjal razvojna dogajanja $v$ teh območjih, zato lahko pričakujemo nadaljnjo preobrazbo teh območij in sicer na tista, ki bodo težila h konkurenčnemu kmetijstvu in na druga, v katerih se bo uveljavljalo ekstenzivno kmetijstvo, oz. se bo kmetijska proizvodnja postopno opuščala. Pričakovati je domala podoben proces kot v drugih zahodnoevropskih deželah.

Območja ekstenzifikacije: To so območja, kjer je mogoče uveljaviti tudi oblike ekstenzivnega kmetovanja ob nižjih stroških, npr. posebne oblike paše ipd. To so predvsem območja, ki se danes že zaraščajo in je ekstenzivna raba možna (priporočljiva) kot oblika zaustavljanja zaraščanja. $\mathrm{V}$ tem primeru pa je pomemben premislek o upravičenosti tovrstnih prizadevanj zaradi varstvenih razlogov, predvsem varstva naravnosti in biotske raznovrstnosti. Možnost izrabe pašniško - travniških površin je komplementarna z ohranjanjem živinoreje. Zato se ekstenzifikacija kaže kot pomembna alternativa sodobnim intenzivnim živinorejskim obratom v nižinskih območjih. Območij, kjerje šenaprej smiselno dodatno uveljavljati pašniško - travniške površine, je pri sedanji stopnji gozdnatosti tudi vse manj. Prihodnja dogajanja so tudi močno odvisna od kmetijske politike, ki bo zaživela samo ob ustreznih proračunskih sredstvih. Ker pa teh, po pravilu, ne bo nikoli dovolj, bo obstoj tega tipa kmetovanja bolj odvisen od ustreznih tehnologij in organizacijskih prijemov. Tudi med strokovnjaki, ki se zavzemajo za take ekstenzivne oblike in jih znajo tudi tehnološko opredeliti, velja, da je poglavitna ovira uveljavljanju tovrstnih tehnologij v razdrobljenosti kmetijstva. Ekstenzivno kmetijstvo je lahko uspešno samo na (zelo) obsežnih površinah na katerih je mogoče enotno gospodariti. Pri tem pa je (bo) drobna lastniška struktura lahko pomembna ovira.

Marginalna območja: To so območja, na katerih kmetijstva $v$ danih družbenih in ekonomskih razmerah ni smiselno podpirati. Gre za območja s težkimi naravnimi pogoji in ga je smiselno prepustiti zaraščanju oz. načrtnemu usmerjanju zaraščanja v ustrezne gozdne 
sestoje. Ta območja zajemajo skoraj tretjino slovenskega ozemlja in tu je obstoj znatnega dela podeželskih naselij ogrožen.

$\mathrm{Ne}$ glede na nakazano členitev podeželja pa lahko tudi $\mathrm{v}$ prihodnje upravičeno pričakujemo, da bo razvoj podeželja v veliki meri odvisen od razvoja omrežja srednje velikih mest, pri čemer je pričakovati relativno povečevanje konfliktov med kmetijsko in nekmetijsko rabo, povečevanje posesti pri čistem kmečkem prebivalstvu, ki pa kljub temu zvečine ne bo zadostovala za rentabilno kmetijsko pridelavo, porajanje konfliktov pri "polkmečkih" gospodinjstvih in propadanje drobne posesti polkmetov ${ }^{1}$, specializacijo kmetijske pridelave, razvijanje številnih dopolnilnih dejavnosti na podeželju, pri čemer bo turizem privilegirana dejavnost. Podeželje izpolnjuje zelo pomembno funkcijo, povezano z naraščajočim pomenom izkoriščanja rekreacijskih potencialov na podeželju, prostim časom in turizmom (sinergija med turizmom, sonaravnim kmetovanjem in kmečkim načinom življenja), uveljavljanjem blagovnih znamk na podeželju, ponovnem vračanju živilskih (tudi tradicionalnih) obratov na podeželje, razvoju različnih oblik pomoči kmetom za izgubljeno pridelavo na kmetijah - tudi zaradi vzdrževanja kulturne pokrajine. Podeželje ima osrednji pomen pri ohranjanju naravnih življenjskih funkcij. Te zadnje funkcije so $\mathrm{z}$ gospodarskega vidika komaj donosne, toda $\mathrm{z}$ vidika trajnostnega razvoja so nepogrešljive.

\section{SKLEPNE MISLI: IZHODIŠČA ZA RAZVOJNE STRATEGIJE}

Načinipospeševanjarazvoja(strukturnošibkih)podeželskihobmočijspomočjoregionalnopolitičnih instrumentov so že dlje časa poznani. Slovenija hkrati uvaja novo regionalno politiko in dosedanje pospeševanje, temelječe pretežno na »infrastrukturni« naravnanosti investicijskih ukrepov nadomeščajo novi, ki zagovarjajo večjo učinkovitost gospodarskih alokacij iz javnih sredstev. S temi ukrepi tudi na podeželju pridobivajo na pomenu konkurenčnost in lokalne iniciative. Oboje pa zahteva sočasno oblikovanje integriranih strokovnih podlag s katerimi je mogoče medsebojno povezati vse akterje. Upadanje prebivalstva, demografske spremembe (staranje) in poslabševanje gospodarskih podlag močno omejujejo razvojne perspektive.

\footnotetext{
${ }^{1}$ O dejanskem razvoju posestne strukture kmečkih gospodarstev v Sloveniji v prihodnosti so možne zgolj špekulativne napovedi. Močnejše spremembe v velikosti gospodarstev v smeri bipolarizacje gospodarskih struktur (kapitalskoindustrijsko povečevanje kmetij na eni in drobne družinske kmetije na drugi strani) je pričakovati v ravninskem delu. Pretežna večina majhnih kmetij pa ne predstavlja dobre podlage za organizirano rast gospodarskih struktur v tem sektorju; samo resnično inovativni in podjetniški kmetje bodo lahko na podlagi pričakovane večje mobilnosti zemljišč povečali svojo obdelovalno površino. Tisti, ki bi lahko v tem uspeli, bodo tudi z zakupom povečali svoje gospodarstvo. Nastala bodo velika kmečka gospodarstva in tudi družinska podjetja z intenzivno kmetijsko proizvodnjo, ki se bodo specializirala predvsem v nekaterih proizvodnih vejah kot so npr. sadjarstvo, vinogradništvo, prašičereja, poljedelstvo itd. Pretežna večina kmečkih gospodarstev se bo usmerila v dopolnilne dejavnosti. Na za kmetijsko pridelavo neugodnih območjih bo verjetno sledilo nadaljnje propadanje kmečkih gospodarstev. Posledica tega razvoja bo povečanje neobdelanih zemljišč in praznjenje teh območij. Tista območja, ki so v bližini zaposlitvenih središč ali predstavljajo potencial za usmeritev v turistična območja, bodo svojo strukturo poseljenosti obdržale. Razmere so najbolj kritične v višje ležečih gorskih in nekaterih obmejnih območjih.
} 
Pričujoča razmišljanja temelje na kompleksnih interakcijah med prebivalstvenim razvojem in zaposlitvenimi možnostminalokalniravni, ki soposledica spremenjenih gospodarskih in socialnih razvojnih izzivov, ki se jima morata tako prebivalstveni kot zaposlovalski segment prilagoditi. Temelje tudi na predpostavki, da samo kmetijstvo z razvojem delovnih mest ne more zagotavljati stabilnega naselbinskega in ekonomskega razvoja na podeželju. Na tej podlagi smo oblikovali dinamičen simulacijski model, ki lahko osvetljuje novo razvojno dinamiko. Model je kombinacija teoretskih podlag iz regionalne ekonomike in socialno-geografske analize razvojnih možnosti podeželja ter izhaja iz naravnih pogojev. Analitično podlago predstavlja opis vzrokov o zatečenem stanju in obsegu gospodarsko naravnanih dejavnosti ter se sestoji iz dveh temeljnih komponent. Na eni strani upodablja fizično in socialno-geografsko okolje, relevantno za konkretno geografsko območje (npr. strukturno analizo: spremembe v strukturi prebivalstva, spremembe $\mathrm{v}$ gospodarski strukturi, spremembe političnih pogojev) na drugi strani pa mora model še zaobseči vedenje akterjev, kako v različnih situacijskih pogojih zaradi medsebojnega učinkovanja reagirajo (npr. medpodjetniška koordinacija pri oblikovanju skupne strategije, ukrepi za pospeševanje okolju prijaznih oblik gospodarjenja, oblikovanje marketinških posledic za razvoj gospodarskih aktivnosti na podeželju). Poleg tega simulacijski model omogoča preučevanje učinkov povratnega delovanja, razsežnosti vplivov in učinkovitost ukrepov.

Shema : Model kompleksne simulacije dinamičnega razvojnega pospeševanja podeželja. Sheme: Model of complexic simulation of dynamic development of rural areas

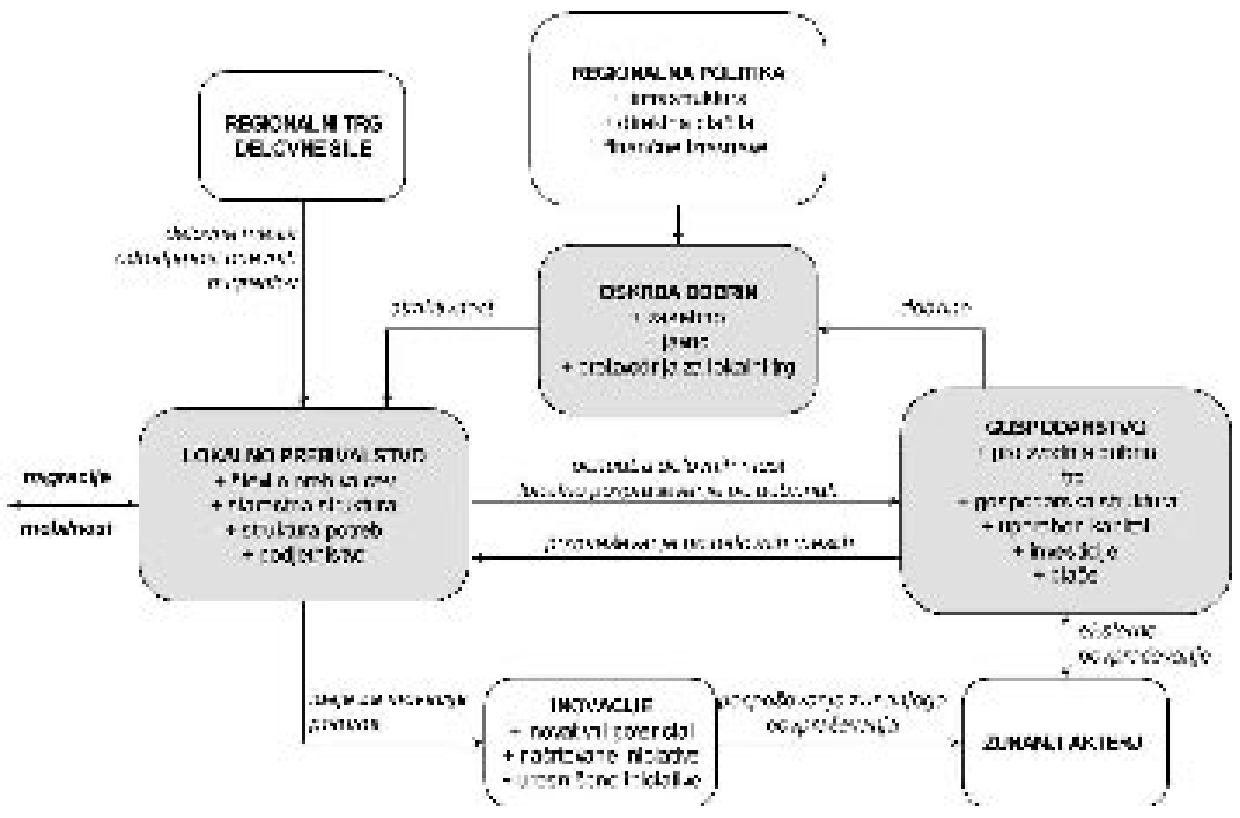

(prirejeno: po Kopainsky, 2005) 
Zgoraj predstavljeni simulacijski model je sestavljen iz dveh skupin razvojnih modulov. Notranji sloni na medsebojni povezanosti učinkov med prebivalstvom, gospodarskim razvojem in pretokom dobrin, ki sestavljajo endogene faktorje in procese znotraj geografsko zaokroženega podeželskega območja. Seveda pa je razvoj odvisen od zunanjih, eksogenih faktorjev, ki skupaj součinkujejo z razvojnimi impulzi. Rast eksternega povpraševanja namreč dolgoročno stimulira lokalno gospodarstvo. Med zunanjimi akterji imata odločujočo vlogo konsistentna regionalna politika in inovacije. Sporočilnost pričujočega modela je še v tem, da omogoča proučevanje medsebojnega součinovanja med proizvodnimi faktorji dela in kapitala in aplikacijo s preostalimi dejavniki kot so: vloga lokalnega okolja in inovacij, ki imata odločujočo vlogo pri razvoju zaposlovanja na podeželju kot ključnem elementu njenega obstoja.

\section{Literatura}

Barbič, A., 2005: Izzivi in priložnosti podeželja. Založba FDV, Ljubljana, 343. str.

Bryant, C., 1997: L'agriculture périurbaine : l'économie politique d'un espace innovateur. Cahiers Agricultures, Zvezek 6, str. 125-130, Paris.

Geografski terminološki slovar, 2005. Uredili: Kladnik, D., Lovrenčak, F., Orožen Adamič, M., Založba ZRC, 451 str, Ljubljana.

Gosar, L., 1982: Poselitvena problematika SR Slovenije, Sinteza raziskav, Urbanistični inštitut SRS, 1.zvezek: 212 str., 2. zvezek: 155 str. Ljubljana.

Klemenčič, V., 1953: Urbanizacija okolice Kamnika. Geografski vestnik XXV, str. 73-91, Ljubljana.

Klemenčič, V., 1960, Problemi gospodarsko - geografske klasifikacije slovenskih naselij. Geografski vestnik XXXII, str. 111-125, Ljubljana.

Klemenčič, V., 1991: Tendence spreminjanja slovenskega podeželja, Geografski vestnik LXIII, str. 25-39, Ljubljana.

Klemenčič, V., 2005: Poskus opredelitve sodobnih problemov razvoja kulturne pokrajine slovenskega podeželja, Dela 24, str. 171-184, Ljubljana.

Kokole, Vl. in Kokole, Ve., 1969: Urbanizacija podeželja v Sloveniji. Geografski vestnik XLI, str. 3-23, Ljubljana.

Kokole, Vl., 1969: Klasifikacija naselij. Tipologija ruralnih sredina u Jugoslaviji, Zagreb.

Kokole, Vl., 1988: Struktura omrežja podeželskih (nemestnih) naselij SR Slovenije. Geografski vestnik LX, str. 65-82, Ljubljana.

Kopainsky, B., 2005: A system dynamic analysis of socio-economic development in lagging Swiss regions. Shaker Verlag, Aachen.

Kopainsky, B., Rieder, P., 2005: Wie weiter mit der dezentralen Besiedlung in der Schweiz? Abschätzung von Entwicklungperspektiven aufGemeindeebene. Geographica Helvetica, Jg 60, Heft 4, str. 239-247.

Kovačič, M., Gosar, L., Fabijan, R., Perpar, A., Jakoš, A., Gabrovec, M. 2000: Razvojnotipološka členitev podeželja v Republiki Sloveniji. Inštitut za agrarno ekonomiko, Oddelek za agronomijo, Biotehniška fakulteta Univerze v Ljubljani, 129 strani, Ljubljana. 
Mihevc, P., 1977: Opredeljevanje vsebine ruralnih naselij za potrebe njihovega usmerjanja. Urbanistični inštitut SRS, 252 str. Ljubljana.

OECD, 2002: OECD Prüfbericht Raumentwicklung Schweiz. Paris: OECD.

Ravbar, M., 1997: Slovene cities and suburbs in transformation (slovenska mesta in njihova obmestja v preobrazbi). Geografski zbornik, št. XXXVII, str. 64-109, Ljubljana.

Ravbar, M., 2004: Razpotja naselbinskega omrežja v Sloveniji: težnje, razvojne dileme in možni scenariji. IB revija, letnik XXXVIII, št. 4, str: 41-52, Ljubljana.

Ravbar, M., Kladnik, D., 2003: Členitev slovenskega podeželja. Geografija Slovenije 8, Založba ZRC, 196 str, Ljubljana.

Sedlar, S., 1974: Vpliv urbanizacije na podobo in strukturo podeželskih naselij v Sloveniji. Univerza v Ljubljani, FAGG, Ljubljana.

Skumavec, D., 2005: Pokrovnost v Sloveniji 1993 - 2001, SURS, št. 815, 68 str, Ljubljana.

Vrišer, I., 1965: Geografska izhodišča pri omejevanju mest in njihovih vplivnih območij. Geografski vestnik XXXVII, str. 143-160, Ljubljana.

Vrišer, I., 1974: Mesto in podeželje - eden od aspektov socialnega razlikovanja. Geographica Slovenica 3, str. 108-119, Ljubljana.

\section{PUTTING SLOVENE COUNTRYSIDE TO THE TEST - who will replace agriculture?}

\section{Summary}

Agriculture in Slovene countryside has lost its leading role in the economic development some time ago. The countryside and its development are depending more and more on the nearby employment centre. Economic structure changes of the countryside (that we have been observing for decades now) are the consequences of several complex and contradictory processes, all diverse from a geographical point of view. There is an ever stronger impression that the transformation reflects the economic and structural changes, linked with sociodemographic and employment development in non-agricultural activities. Furthermore the intensive transformation of agriculture in the countryside fits with its economic lag.

In the paper we are assessing the link between countryside development and the level of urbanization. Through critical thinking we are pointing out the trends that contradict planned goals. We are particularly emphasizing the developmental questions regarding overgrowthprocesses and we are discussing whether it is possible to speed up the process of farm-property concentration. How is economic development in the countryside going to be like and how far from city-centers can an expansion of urbanization be expected?

Evaluating the possibilities in countryside development offers a division into several typical areas, i.e. areas of competitive market-agriculture (1), where activities are intensifying (these areas are rare in Slovenia). Areas of countryside activity diversification (2) where agriculture needs the support of other economic activities, particularly to preserve a certain population density and to support other economic activities, e.g. tourism. Areas of extensification (3), where it is possible to impose forms of low-cost extensive farming, e.g. 
special forms of grazing, and marginal areas (4), where supporting agriculture is not sensible due to difficult physical conditions in social and economic circumstances.

Regardless of the possible division we can expect the development of the countryside in the future to become largely dependent on the development of a middle-sized city network. Thereby a relative increase in conflict situation between agricultural and non-agricultural land uses are expected since even an increase in land property of professional farmers in most cases will not make farming a rentable activity. Through simulation of developmental consequences in several typical areas of different developmental possibilities and the help of a simulation model, we offer at the end a possible direction for future development. The new regional policy stands for a greater efficiency of economic allocations from public means. These acts bring competitiveness and local initiative to the countryside and both demand a simultaneous formation of integrated professional groundwork that enable to combine several actors. 